\title{
Exploratory Factor Analysis (EFA) of Website Design Factor for Airlines E- Ticketing System in Malaysia
}

\author{
"Nor Alina Binti Ismail \\ Faculty of Engineering, Build Environment \& IT, SEGi University \\ *noralinaismail@ segi.edu.my
}

\begin{abstract}
The main motivation of this study was to investigate the level of satisfaction towards online purchasing among people those had experience using airlines e-ticketing websites in Malaysia. This paper highlights the detail of exploratory Factor Analysis (EFA) procedure that tested on web design towards airlines e-ticketing website in Malaysia. The result was written based on findings of a survey conducted among Malaysian and non-Malaysian customer. The study was further down tested into website design factor. The samples of this study were 510 respondents from all over Malaysia area. The study obtained samples by using random sampling method. The finding based on the EFA result of the survey.
\end{abstract}

Keywords: E-ticketing System, EFA, Transaction Cycle, Pre-purchase Construct, Website Design

\section{Introduction}

Online purchasing means that the world now faced a rapid growth with the use of Internet where people around the world can easily access information and making reservation or placing an order online. This online purchasing has been widely used recently in this world of Information Technology. Many airlines companies especially in Malaysia now have implemented this method in their commercial websites. Companies make an online transaction / purchasing as an investment that helps them in the scope of expanding their market leadership. By having an online purchasing method / system, it will lead to superior control over the reservation process and 
operation with greater accuracy and thus also helps to reduce errors due to conventional manual processing.

Usually, online shopping will involves seeking an information and carrying out all the activities and steps that provide the customers the information that help them to arrive at an informed decision and conduct business. On the other hand, online transaction represents technological infrastructure used to exchange data and purchase product or service electronically (Sulaiman et al, 2009).

However, there are still a few problems that users might face when make an online transaction. The possible problems may include; 1) the user may not find their intended page after spending much time searching information through web pages which; 3) the user have to pay extra money for extra charges; 4) the website is not really updated (Amiruddin and Chang, 2005).The purpose of this study is to highlight the efficiency of website design towards airline e-ticketing systems in Malaysia.

\section{Literature review}

Most of the internet user nowadays prefer conventional booking than online booking. Customers / internet user were willing to trust traditional methods compared to online platform Based on the previous study, about $30 \%$ of the customers have not bought anything from Internet because they found unsecured of sharing their information online. Which means the design of website is not unconvincing enough (Amirruddin and Chang, 2005).

Besides, most of customers those prefer do an online transaction compared to traditional transaction because of the design factor for the website such as it is easy to search information, attractive page layout with professional web style and readability website page (Stephen, 2013). The information content on the website will have significant impact on the satisfaction and loyalty of airline companies in Malaysia including MAS, Air Asia, Malindo, FireFly and MASWings. In fact, the design quality of the website is another important reason influencing customers' trust.

Based on the previous study did by Clay et al, (2009), customers faced more risk for online transaction especially in pre-purchase stage compared to traditional purchase at counter. Most of the customers feels that they are easier to get information and compared the prices of the books from Internet than normal world. Hence, 
respondents are not worried about the security issues when make an online purchasing. The customers also will choose online booking because of the time reduction.

In addition, online transaction is easy to know the price, product details and also any promotion that offer by the companies to their customers. The customer tend to book or purchase flight ticket online because they feel easy to deal with all the website features that provided by the companies (Benjamin, 2016).

The primary reason why customer choose online transaction because it including, convenience, lower fares, and lower information search costs. Customers also makes transaction via online booking ticket price (RSD Business and Industry, 2004). It is because the cost saving is play an important role which encourage customer to make online booking transaction (Hoque, 2018).

The study of Will (2015) found that customers could search for information likes prices, product information, flight schedule and other information and will compare with other websites before make purchasing. Besides, online transaction can let customer save time such as mitigate traffic jams during peaks season. Also, customers can choose their seat and class of travel when make online transaction with any airline companies. They will receive a confirmation email from the company after they make purchasing (www.malaysiaairlines.com, 2020).

\section{Methodology}

The methodology used in this study was based on certain techniques, which was for collecting data. The survey was done among Malaysian and non-Malaysian those had experience using any airline e-ticketing system in Malaysia (covered MAS, AirAsia, Malindo, FireFly and MASWings).

The survey consisted a variety of questions and options that including had different levels which were included:

a) Respondents satisfactory level during pre-purchase stage

b) Respondents satisfactory level during purchase stage

c) Respondents satisfactory level during post-purchase stage 
All the stages are covers the elements of online transactions that adapted from previous and currents studies (Alhiou et al, 2009). The survey questions were designed to identify the level of satisfaction and loyalty among customers which had experience using airline e-ticketing systems in Malaysia.

This paper highlighted the finding of respondent satisfactory level during prepurchase stage specifically on web design factor.

\section{Results and discussion}

In this section, the result of this paper will be discussed. The EFA result of website design in the pre-purchase stage has been highlighted in this section since the paper's objective is to highlight the efficiency of website design towards airline eticketing systems in Malaysia.

\subsection{Result of exploratory factor analysis (EFA)}

Exploratory Factor Analysis (EFA) is a generally applied statistical technique in the social science study (Hair et al, 2010). This EFA procedure can be defined as "a multivariate statistical procedure applied to reduce large number of factors into a smaller set of factors, establishes dimensions and provides construct validity to name a few". The researchers adapted instruments from previous study then modified some items on order to make sure it fit to current study. Hair et al, (2010) added, if the statements to fit the current study, the researcher need to conduct the EFA procedure.

Exploratory factor analysis is a statistical technique used to reduce data to a smaller set of variables. Table 1 shows that the EFA procedure has extracted two components. In this study, only factor loadings above 0.5 will be retained.

Table 1. EFA for website design construct (Source: Nor Alina Ismail, 2018)

\begin{tabular}{|c|c|c|}
\hline Construct_Code & Factor 1 & Factor 2 \\
\hline Website_Design3 & .791 & \\
\hline Website_Design2 & .702 & \\
\hline Website_Design1 & & .595 \\
\hline
\end{tabular}

As displayed in Table 1, the website design items were loaded into two factors. Website_Design3 and Website_Design3 were loaded into Factor1 while 
Website_Design1 was loaded into Factor2. Factor1 and Factor2 were renamed as website features and loyalty program. It is interesting to note that although Website_Design1 was posited to be categorized as Website_Design, the result of EFA did not support this view. In fact, it was loaded into Factor2, which indicated that they should measuring loyalty program instead of website design.

The website features of each airline e-ticketing website mustinclude the elements of website design, searching an information, pricing and also the promotions (Benjamin et al, 2003; Byambaa et al, 2012). The elements of website design were included attractive, interactive and informative. This three main elements also apart of how easy customer can seek an information which including seeking about the travel and destination, flight schedule or availability, frequent flyer information, an online entertainment and pricing and promotions information.

In this study, the "website features" was chosen as supported by past studies of Benjamin (2016). While the "loyalty programme" and "promotions" factor was remain as the result of EFA shows that all the items are strongly belong to the particular factor.In summary, this study had used all the three factors, as derived from EFA results for measuring pre-purchase construct in e-transaction cycle.

While the KMO and Bartlett's Test results of the study is presented in Table 2 as follow:

Table 2. KMO and bartlett's test for pre-purchase

\begin{tabular}{|c|c|}
\hline $\begin{array}{c}\text { Kaiser-Mayer-Olkin Measure of Sampling } \\
\text { Adequacy }\end{array}$ & .898 \\
\hline Bartlett's Test of Sphericity & 4668.3 \\
\hline
\end{tabular}

The general acceptance index of KMO is over 0.6. Table 2 shows the KMO value of 0.898 is excellent as it exceeds the recommended value of 0.6. The significance value of Bartlett's Test of Sphericity must less than 0.05 for the factor analysis to be acceptable. The Bartlett's test significance value is 0.000 which meet the required significance value of less than 0.05 (Hoque et al, 2016). Therefore, KMO value is very close to 0.9 / 1 at the significance level of 0.000.This result implying factors analysis was suitable and significant. 


\section{Conclusion}

Today's technology world, virtual community has been considered as an important criterion for attracting and maintaining long term relationship with customers., thus many companies for enhancing their performance need to put the online shopping environment in the centre of their focus.

This research provides the thorough understanding of how most of airlines in Malaysia applies factors in order to determine the level of satisfaction towards their companies. This is can be concluded that most of airlines in Malaysia now choose to use an internet as a platform to them to sell their flight ticket to the customers. From the finding received, most of participants are not really happy with the electronic services like website check-in that provided by airlines companies. Perhaps, this finding will help the company to improve their services and business skill in future in order to meet their customer's needs.

\section{References}

Ainin, S., Josephine, N., \& Suhana, M.(2006). E-ticketing in Malaysia: Usage Trends. The $10^{\text {th }}$ Pasific Asia Conference on Information System (PACIS, 2006). pp 68-82

Ainin, S., Josephine, N., \& Suhana, M.(2008). E-tieckting as a New Way of Buying Tickets: Malaysian Perceptions. Journal of Social Science, Vol. 17(2). pp. 149-157

Alhaiou, T.2011. An Empirical Study on Electronic Customer Relationship Management (E- CRM) Implementation and E-loyalty at Different Adoption Stages of Transaction Cycle. (Published PhD's Thesis). United Kingdom: University of Brunel.

Benjamin, C.Y.F., Aw, Y.C., \& Damoon, Y. (2013). An Exploratory of Airline ETicket Purchasing Intention Among Foreign Undergraduates in Malaysia. Journal of Human and Social Science Research. Vol. 1 (1), pp. 51-61.

Byambaa,B. \& Chang, K.C. (2012). The Influence Factors of Online Purchase on Customer Satisafction in Mongolian Airlines. Vol.57(15), pp. 80-85.

Hair, J.F., Anderson, R.E., Tatham, R.L., \& Black, W.C. (2010). Multivariate Data Analysis, 7th, Prentice Hall, Englewood Cliffs, New Jersey.

Hoque, A.S.M.M.; \& Awang, Z. (2016a). Exploratory Factor Analysis of Entrepreneurial Marketing: Scale Development and Validation in the SME context of Bangladesh.

Hoque, A.S.M.M.; \& Awang, Z. (2016b). The Sway of Entrepreneurial Marketing on Firm Performance: Case of Small and Medium Enterprises (SMEs) in Bangladesh. Hoque, A.S.M.M.; Awang, Z.; \& Ghani, N. A. (2016). Conceptual Model for Quality of Life in the Perspective of Social Entrepreneurship. 
Hoque, A.S.M.M.; Awang, Z.; \& Siddiqui, B.A. (2018). Role of Employee Engagement on Compensation System and Employee Performance Relationship among Telecommunication Service Providers in Bangladesh. International Journal of Human Resource Studies, 8(3), 19-37.

Will (2014). Information Technology's Strategic Impact on the Air Travel Service Industry. Journal of Information \& Management for American Airlines, 15(2), pp. $24-56$ 